\section{Response of Container-grown Ninebark to Crude and Nutrient-enriched Recirculating Compost Leachates}

\author{
Joanna Gils, Calvin Chong, and Glen Lumis \\ Department of Plant Agriculture, University of Guelph, Guelph, Ont., N1G \\ 2W1, Canada
}

Additional index words. fertigation, nutrition, ornamentals, nursery production

\begin{abstract}
Ninebark [Physocarpus opulifolius (L.) Maxim] was grown on troughs under greenhouse conditions in 2.5 - $\mathrm{L}$ containers filled with $100 \%$ composted pine bark and fertigated with drip irrigation using the following nutrient solutions: 1) a complete (control) solution, electrical conductivity (EC) of $1.75 \mathrm{dS} \cdot \mathrm{m}^{-1}$, nonrecirculated; 2) solution as in treatment 1 but recirculated; 3) unamended municipal solid waste compost (MSW) leachate, EC 1.75 $\mathrm{dS} \cdot \mathrm{m}^{-1}$, recirculated; 4) solution as in treatment 3 amended in order of priority with $\mathrm{NO}_{3}-\mathrm{N}$, $\mathrm{NH}_{4}-\mathrm{N}, \mathrm{P}, \mathrm{K}, \mathrm{Ca}$ and/or $\mathrm{Mg}$, to match the concentrations in the complete solution, EC 2.60 $\mathrm{dS} \cdot \mathrm{m}^{-1}$, recirculated; 5) unamended turkey litter compost (TLC) leachate, EC $1.75 \mathrm{dS} \cdot \mathrm{m}^{-1}$, recirculated; and 6) solution as in treatment 5 amended as in treatment 4 , EC $2.40 \mathrm{dS} \cdot \mathrm{m}^{-1}$, recirculated. Among the four recirculated compost leachate treatments, shoot (stems and leaves) dry weight of ninebark was least with the unamended MSW, intermediate with amended MSW, and greatest but similar with both unamended and amended TLC. The most growth occurred with the recirculated control solution. Among the four leachate treatments, ninebark grew acceptably well only with recirculated unamended TLC, and was similar to that with the nonrecirculated control solution. Three treatments (nonrecirculated control, recirculated control and unamended TLC) showed no nutrient toxicity or deficiency symptoms. Poorer growth responses in the other treatments (amended TLC, amended MSW and unamended MSW) were related primarily to excess salts and/or nutritional disorders due to imbalance(s) in one or more nutrients.
\end{abstract}

Global concerns about water quality and scarcity, as well as increasing environmental regulations to prevent surface and ground water contamination from nutrient-laden effluents, have prompted the evaluation of alternative sources of water for agricultural irrigation and the recycling of nutrients in plant culture (Fitzpatrick, 1984; Jarecki et al., 2005; Poole and Conover, 1992; Purvis et al., 2000).

Compost leachate is a potential source of water and fertilizer for growing nursery stock (Jarecki et al., 2005; Schwarz, 1985). Composts such as spent mushroom, turkey litter and municipal waste are rich in certain nutrients (Bunt, 1988; Chong, 2002; Schulz and Romheld, 1997). Jarecki (2002) reported increased growth of five tree and one grass species in field plots fertigated with nutrient-fortified pond-collected spent mushroom compost leachate. Michitsch et al. (2003) successfully grew 'Lynwood' forsythia (Forsythia $\times$ intermedia Zab. 'Lynwood') and 'Red Prince'

Received for publication 12 Nov. 2004. Accepted for publication $24 \mathrm{Feb}$. 2004. This paper is a portion of a thesis submitted by Joanna Gils in fulfilling a Master of Science degree requirement. Financial support was provided by Ontario Ministry of Agriculture and Food (OMAF); Natural Sciences and Engineering Research Council of Canada (NSERC); National Research Council of Canada, Industrial Research Assistance Program (IRAP); Landscape Ontario Horticultural Trades Association Grower's Group; and Landscape Ontario Horticultural Trades Foundation. weigela [Weigela florida (Bunge.)A. DC. 'Red Prince'] in greenhouse hydroponic solutions containing both crude and nutrient-enriched solutions from spent mushroom and municipal solid waste composts, and also from crude wastewater derived from anaerobic digestion of municipal solid wastes.

The objective of this study was to evaluate the response of container-grown ninebark fertigated with both crude and nutrient-enriched compost leachates from municipal solid waste and turkey litter composts in a recirculating system.

\section{Materials and Methods}

Compost leachates. The compost leachates were prepared as described by Weltzien (1992). Finished municipal solid waste compost (MSW; Wet-Dry Recycling Centre, Guelph, Ont., Canada) or finished turkey litter compost (TLC; Cole Springs Farm, Thamesford, Ont., Canada) was mixed with deionized water (1: $1, \mathrm{v} / \mathrm{v}$ ) and fermented with daily stirrings for $7 \mathrm{~d}$ at room temperature. The compost-water mixtures were filtered through cheesecloth (28 $\times 24$ threads $/ 2.5 \mathrm{~cm}^{2}$ ) and then through a 155 mesh screen. The crude leachates [electrical conductivity, $\mathrm{EC} \simeq 11$ and $13 \mathrm{dS} \cdot \mathrm{m}^{-1}$ for MSW and TLC, respectively] were dispensed in 30-L batches and frozen at $-18{ }^{\circ} \mathrm{C}$. When required, batches were thawed at room temperature and diluted with reverse osmosis-treated water to an EC of $1.75 \mathrm{dS} \cdot \mathrm{m}^{-1}$. The initial chemical composition of the diluted or unamended compost leachates(uMSW and uTLC) are shown in Table 1.

Plant material and cultural conditions. Plug-rooted liners of 18 to $20 \mathrm{~cm}$ tall common ninebark [Physocarpus opulifolius (L.) Maxim] were grown in 2.5-L (\#1) nursery containers in a glasshouse $\left(93 \mathrm{~m}^{2}\right.$; natural photoperiod) at the University of Guelph, Guelph, Ont., Canada (lat. $43^{\circ} 33^{\prime} \mathrm{N}$, long. $80^{\circ} 15^{\prime} \mathrm{W}$ ) from 26 Apr. to 19 July 2002. The average day/night temperatures were: $21 \pm 0.7^{\circ} \mathrm{C} / 17$ $\pm 0.3{ }^{\circ} \mathrm{C}$ from 26 Apr. to 24 May; $22 \pm 1.1^{\circ} \mathrm{C} /$ $18 \pm 0.8^{\circ} \mathrm{C}$ from 24 May to 21 June; and 23 $\pm 1.0{ }^{\circ} \mathrm{C} / 19 \pm 1.0^{\circ} \mathrm{C}$ from 21 June to $19 \mathrm{July}$. The average relative humidities during these same periods were: $36 \% \pm 14 \% ; 61 \% \pm 13 \%$; and $70 \% \pm 12 \%$, respectively. The substrate was $100 \%$ composted pine bark ( 0.9 to 1.3
Table 1. Initial chemical composition of the six nutrient solutions. ${ }^{z}$

\begin{tabular}{lcccccc}
\hline Variable & $\begin{array}{c}\text { Recommended } \\
\text { concn }^{\mathrm{x}}\end{array}$ & NRC, RC & uMSW & uTLC & aMSW & aTLC \\
\hline $\mathrm{EC}$ & $<3.0$ & 1.75 & 1.75 & 1.75 & 2.60 & 2.40 \\
$\mathrm{NO}_{3}-\mathrm{N}$ & $100-199$ & 147 & 18 & 100 & 147 & 147 \\
$\mathrm{NH}_{4}-\mathrm{N}$ & --- & 14 & 2 & 1 & 14 & 14 \\
$\mathrm{P}$ & $6-9$ & 39 & 3 & 29 & 39 & 39 \\
$\mathrm{~K}$ & $150-250$ & 156 & 173 & 276 & 173 & 276 \\
$\mathrm{Ca}$ & $200-300$ & 140 & 31 & 25 & 140 & 140 \\
$\mathrm{Mg}$ & $70-200$ & 34 & 12 & 50 & 34 & 50 \\
$\mathrm{SO}_{4}$ & $<200$ & 144 & 152 & 160 & 152 & 160 \\
$\mathrm{Cl}$ & $<355^{\mathrm{w}}$ & 0 & 260 & 92 & 260 & 200 \\
$\mathrm{Na}$ & $<70$ & 0 & 194 & 60 & 194 & 60 \\
$\mathrm{HCO}$ & $<150-200$ & 13 & 189 & 86 & 42 & 50 \\
$\mathrm{Zn}$ & $<2.0$ & 0.23 & 0.14 & 0.15 & 0.14 & 0.15 \\
$\mathrm{Mn}$ & $<1.0$ & 0.27 & 0.09 & 0.25 & 0.09 & 0.25 \\
$\mathrm{Cu}$ & $<0.2$ & 0.05 & 0.04 & 0.07 & 0.04 & 0.07 \\
$\mathrm{Fe}$ & $<5.0$ & 1.40 & 1.46 & 0.56 & 1.46 & 0.56 \\
$\mathrm{~B}$ & $<0.8$ & 0.22 & 0.19 & 0.30 & 0.19 & 0.30 \\
$\mathrm{Mo}$ & $<0.07$ & 0.05 & 0.04 & 0.02 & 0.04 & 0.02 \\
\hline
\end{tabular}

${ }^{2} \mathrm{NRC}=$ nonrecirculated control; $\mathrm{RC}=$ recirculated control; $\mathrm{uMSW}=$ unamended municipal solid waste; aMSW = amended municipal solid waste; uTLC $=$ unamended turkey litter compost; aTLC $=$ amended turkey litter compost.

${ }^{\mathrm{y}}$ All variables expressed in $\mathrm{mg} \cdot \mathrm{L}^{-1}$ except for $\mathrm{EC}\left(\mathrm{dS} \cdot \mathrm{m}^{-1}\right)$.

${ }^{x}$ Adapted from Ayers and Westcot (1985), Southern Nurserymen's Association (1997), OMAF (2003), Whipker (1999), Reisenauer (1976), and Mathers (2003).

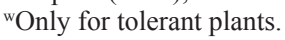


Table 2. Chemical analysis of the growth substrate before first fertigation.

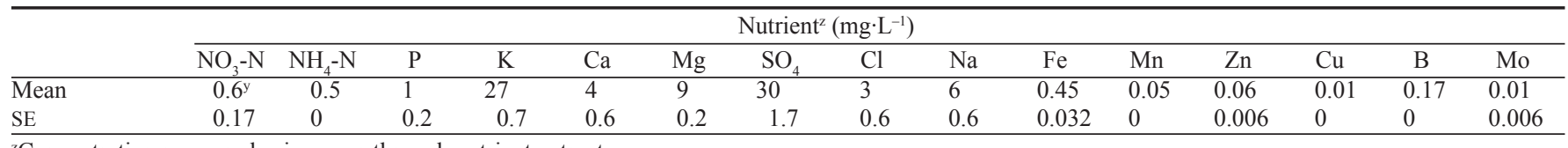

${ }^{\mathrm{z}}$ Concentration measured using pour-through nutrient extracts.

${ }^{\mathrm{y}}$ Each datum is the mean of three samples \pm standard error (SE).

cm size mix; Gro-Bark Organics Inc., Hornby, Ont., Canada), with the following physical properties: total porosity, $71 \% \pm 0.2 \%$; aeration porosity, $34 \% \pm 2.6 \%$; water retention porosity, $37 \% \pm 2.7 \%$; and bulk density, 0.36 $\pm 0.005 \mathrm{~g} \cdot \mathrm{cm}^{-3}$. The chemical composition is shown in Table 2.

Treatment solutions and sampling. Plants were placed $45 \mathrm{~cm}$ apart on aluminum troughs $(2.1 \mathrm{~m}$ long $\times 20 \mathrm{~cm}$ wide $\times 2.5 \mathrm{~cm}$ deep $)$ set at a $3 \%$ slope on four separate benches (each $4.4 \mathrm{~m}$ long $\times 1.4 \mathrm{~m}$ wide $\times 0.8 \mathrm{~m}$ high; 38 $\mathrm{cm}$ pathways between benches). Each trough was accompanied by a $77 \mathrm{~L}$ nutrient supply tank with $60 \mathrm{~L}$ of solution. All solutions were made using reverse osmosis treated water and constantly aerated at a rate of $0.7 \mathrm{~L} \cdot \mathrm{min}^{-1}$ using the greenhouse-equipped compressed air. Leachate from containers in recirculating treatments 2 to 6 flowed into the nutrient supply tank and was recirculated via a submerged pump. Leachate from treatment 1 was directed to a floor drain.

The treatment solutions were (Table 1): 1) a complete (control) solution previously used for greenhouse-grown roses in a recirculating system (Blom, 2002), EC of $1.75 \mathrm{dS} \cdot \mathrm{m}^{-1}$, nonrecirculated; 2) solution as in treatment 1 but recirculated; 3) unamended MSW leachate, EC $1.75 \mathrm{dS} \cdot \mathrm{m}^{-1}$, recirculated; 4) solution as in treatment 3 amended in order of priority with $\mathrm{NO}_{3}-\mathrm{N}, \mathrm{NH}_{4}-\mathrm{N}, \mathrm{P}, \mathrm{K}, \mathrm{Ca}$ and/or $\mathrm{Mg}$, to match the concentrations in the complete solution (treatment 1), EC $2.60 \mathrm{dS} \cdot \mathrm{m}^{-1}$, recirculated; 5) unamended TLC leachate, EC $1.75 \mathrm{dS} \cdot \mathrm{m}^{-1}$, recirculated; and 6) solution as in treatment 5 amended as in treatment 4, EC $2.40 \mathrm{dS} \cdot \mathrm{m}^{-1}$, recirculated. The experimental design was a randomized complete block design with four blocks (benches) and five plants per plot.

Nutrient solutions were applied by a computerized system (Argus Control Systems Ltd., White Rock, B.C., Canada) at a rate of 0.15 $\mathrm{L} \cdot \mathrm{min}^{-1}$ per container through one circular drip emitter (10 $\mathrm{cm}$ diameter) and one supply tube [( $60 \mathrm{~cm}$ long, $0.15 \mathrm{~cm}$ i.d. (Dramm Corporation, Manitowoc, Wis.)]. A leaching fraction of $10 \%$ to $25 \%$ was maintained from the containers (Mathers, 2003).

Every 2 weeks, the partially depleted solution in each supply tank was topped up to the original $60-\mathrm{L}$ volume with fresh solution and/or reverse osmosis treated water at a ratio that retargeted the EC of the solution to the original values (Table 1). The formula used to derive this ratio was (Actual $\mathrm{L} \times$ Actual $\mathrm{EC})+$ [Original EC x $(60 \mathrm{~L}-$ Actual L $-\mathrm{Y})]=(60 \mathrm{~L}$ $\times$ Original EC), where $\mathrm{Y}=\mathrm{L}$ reverse osmosis treated water and $(60 \mathrm{~L}-$ Actual $\mathrm{L}-\mathrm{Y})=\mathrm{L}$ fresh solution (Blom, 2002). After each topping, a 250-mL sample of the solution was analysed for $\mathrm{EC}, \mathrm{pH}, \mathrm{NO}_{3}-\mathrm{N}, \mathrm{NH}_{4}-\mathrm{N}, \mathrm{P}, \mathrm{K}, \mathrm{Ca}, \mathrm{Mg}, \mathrm{SO}_{4}$,
$\mathrm{Cl}$, and $\mathrm{Na}$ (Agri-Food Laboratories, Guelph, Ont., Canada). The $\mathrm{pH}$ was adjusted to $5.5 \pm$ 0.03 weekly using either $93 \%$ sulfuric acid or $1 \mathrm{M}$ sodium bicarbonate.

On 26 Apr. (just before first fertigation), triplicate samples of leachate were collected from the substrate by the pour-through procedure (Wright, 1986), and analysed for EC and $\mathrm{pH}$ (Agri-Food Laboratories, Guelph, Ont., Canada). Leachates were also collected every 4 weeks on 24 May, 21 June, and 19 July from containers in each plot and analysed similarly.

On 19 July (harvest), samples of recentlymatured leaves from each plot were dried at $60{ }^{\circ} \mathrm{C}$, weighed, ground, and analysed for total N, P, K, Ca, Mg, S, Cl, Na, Fe, Mn, Zn, $\mathrm{Cu}$, and B (Agri-Food Laboratories, Guelph, Ont., Canada). The shoots were removed and separated into leaves and stems. The substrate was washed from the roots. Leaves, stems and recovered roots were dried and weighed. The weight of the leaves used for foliar analysis was added back to the remaining leaf dry weight.

Statistical analysis. Analysis of variance for dry weights and foliar nutrient concentrations was performed using Proc GLM, after testing for normality and homogeneity by Proc UNIVARIATE and Proc PLOT. Means between compost leachate treatments were compared by least significant difference (LSD) test, and between the nonrecirculated or the recirculated control solution and each compost leachate by Dunnett's test. Proc CORR was used to test the relationships between dry weights and foliar nutrients, between individual foliar nutrients, and between shoot dry weights and substrate EC. Data for solution nutrient concentrations, $\mathrm{EC}$ and $\mathrm{pH}$, and for substrate $\mathrm{EC}$ and $\mathrm{pH}$, were regressed over time. Using Proc GLM, the model for substrate $\mathrm{EC}$ and $\mathrm{pH}$ represents a series of regression responses, one for each of the six treatment solutions, radiating from a common intercept (Chong and Purvis, 2004). Polynomials were fitted to account for curved relationships $(P \leq 0.05)$ and stepwise contrast analysis was conducted to determine if there was any similarity among the relationships $(P$ $\leq 0.05)$. The coefficient of determination for each set of responses was expressed in terms of partial $r^{2}$, which measured the strength of the response relationship after removing replication effects (Deveau et al., 1987).

\section{Results}

Growth response. Among the four recirculated compost leachate treatments, shoot (leaf and stem) dry weight of ninebark (Fig. 1) was least with unamended MSW, intermediate with amended MSW, and greatest but similar with unamended and amended TLC.
With unamended MSW, ninebark developed chlorosis and scorched leaf tips within two weeks after first fertigation (26 Apr.). By 24 May, symptoms included marginal scorch, dark brown spots and blotches on both old and new leaves, older foliage senescence and lower leaf abscission. By 21 June, leaf margins were curled. At harvest (19 July), leaves were small and growth was sparse, and present only at the ends of slender shoots. Similar or some variation of these symptoms developed progressively later and in order of decreasing severity: amended MSW (leaves small but dark green; lower leaf abscission about $25 \%$ of total canopy at harvest); amended TLC $[\operatorname{mild}(<5 \%)$ leaf scorch by 21 June; and some brown spots and blotches primarily on some older leaves after this date; sprawling growth habit with larger leaves and longer internodes].

In contrast, with unamended TLC and the two control (RC and NRC) solutions, there were no symptoms. Plants grew rapidly in these three treatments and, according to standards of the Canadian Nursery and Landscape Association (CNLA, 2002), attained marketable size even before termination of the experiment. The growth habit was compact and the plants were attractive. Shoot dry weight with uTLC was comparable to that with aTLC, and also with the nonrecirculated control (NRC), but less than with the recirculated control (RC) (Fig. 1). The RC treatment notably produced the greatest shoot dry weight. Stem and leaf dry weights showed similar patterns (Fig. 1), but leaf dry weights for aTLC and RC were similar.

With both TLC solutions, root dry weights (Fig. 1) were similar, comparable with those for NRC and RC, but greater than their MSW counterparts. The shoot/root dry weight ratios were greatest with aMSW, intermediate with aTLC, NRC and RC, and least with the two unamended compost solutions (Fig. 1).

Foliar nutrients. More N, P, Mg, and S tended to accumulate in leaves of ninebark plants grown with TLC than with MSW solutions (Fig. 2). The concentrations of these nutrients were each consistently and positively correlated with each of the growth parameters (Table 3 ). In contrast, most of the remaining foliar nutrients were negatively correlated with one or more growth parameters.

Nutrient changes in solution tanks. Concentrations of $\mathrm{NO}_{3}-\mathrm{N}$ (uMSW), $\mathrm{NH}_{4}-\mathrm{N}$ and $\mathrm{P}$ (all recirculated treatments), $\mathrm{K}$ (uMSW and aMSW), Ca (aMSW) and Mg (uTLC) decreased by between $14 \%$ and $87 \%$ over the course of the experiment, while concentrations of $\mathrm{Mg}$ (except NRC and uTLC), $\mathrm{SO}_{4}$ (all recirculated treatments), $\mathrm{Cl}$ and $\mathrm{Na}$ (aMSW and aTLC) increased by between $13 \%$ and 98\%. The EC values (except NRC and uMSW) 
increased also by between $18 \%$ and $49 \%$. The $\mathrm{pH}$ in the solutions remained relatively stable, changing $<10 \%$ of initial values (data not shown).

Substrate. The EC in all substrates increased throughout most or all of the growing period ( 0.3 to $\left.7.9 \mathrm{dS} \cdot \mathrm{m}^{-1}\right)$, except uMSW, which changed little in EC after 24 May (Fig. 3). Values tended to be greatest with the amended leachates, intermediate with the controls, and least with the unamended leachates.

Corresponding substrate $\mathrm{pH}$ decreased from 26 Apr. (7.4) to about 24 May (5.8 to 6.3) and then increased, changed little or peaked ( 6.0 to 7.0 in mid-July) (Fig. 3). At this time (midJuly), values were the greatest with uTLC, intermediate with aTLC, uMSW and RC, and least with aMSW and NRC. The range of these pHvalues (Fig. 3) are acceptable for containergrown ninebark (Chong, 1999).

\section{Discussion}

The major disadvantages or limitations of using compost leachates in plant culture include: the presence of undesirable chemicals; variability in chemical composition; phytoxicity due to excess salts or specific nutrients; and nutrient deficiencies (BCMAF, 1996; Li et al., 1997; Peot and McIntyre, 2000; Shrive et al., 1994). Excess salts may restrict use to moderately or very salt tolerant species (Schwarz, 1985 ) since it is often difficult to rectify nutrient imbalances (Jarecki, 2002).

In the present study with four recirculated compost leachates, two unamended and two fortified with selected nutrients, container-grown ninebark grew acceptably well only with the unamended recirculated TLC. Fortuitously, both the initial and later concentrations of $\mathrm{NO}_{3}-\mathrm{N}, \mathrm{P}$, and $\mathrm{K}$ in the unamended TLC solution were close to or within normal ranges (Table 1; OMAF, 2003), indicating a reasonable balanced composition of these major nutrients that could account, at least in part, for the good response of ninebark in this solution. The slightly higher $\mathrm{NO}_{3}-\mathrm{N}\left(>147 \mathrm{mg} \cdot \mathrm{L}^{-1}\right)$ in the recirculated control treatment throughout most of the growth period could perhaps account for the enhanced performance of ninebark in this treatment versus that with uTLC. Poorer responses with the other leachates seemed to be related primarily to nutritional disorders and/or imbalances.

The unamended MSW, the worst among the six solutions, was the most imbalanced. It contained sufficient $\mathrm{K}$, but was deficient in $\mathrm{P}$ and lacking substantially in $\mathrm{NO}_{3}-\mathrm{N}$ (18 at $\left.1.75 \mathrm{dS} \cdot \mathrm{m}^{-1}\right)$. As commonly reported in recirculating systems (Böhme, 1995; Sonneveld and Vanderburg, 1991; Zekki et al., 1996), $\mathrm{Na}, \mathrm{Cl}$ and $\mathrm{SO}_{4}$ accumulated most in the unamended MSW solution and its amended counterpart. Concentrations of $\mathrm{Na}$ and $\mathrm{Cl}$ in the MSW leachates were notable up to 3.2 times those in the TLC leachate. In the unamended MSW, deficiency was likely and predominantly due to lack of $\mathrm{N}$ (chlorosis, slender stems, older-leaf abscission) (Marschner, 1986; Rose and Biernacki, 1999) and toxicity likely due to $\mathrm{Cl}$ [(leaf tip and marginal scorch, premature yellowing and abscission of older leaves; negative correlation with shoot growth); (Table 3) (Marschner, 1986; Mathers 2000)], but perhaps not $\mathrm{Na}$ due to the relatively low tissue content $(0.09 \% ;<0.3 \%$ to $0.5 \%$ toxic levels) (Ayers and Westcot 1985; Bergmann 1992). Additional leaf injury symptoms were similar to those described for B toxicity: dark brown spots and blotches accompanied by curling of the leaf margins (Bergmann, 1992). The concentration of $\mathrm{B}$ in the leaf tissue of uMSW plants $\left(78 \mathrm{mg} \cdot \mathrm{kg}^{-1}\right)$ was greater than recommended ( 30 to $50 \mathrm{mg} \cdot \mathrm{kg}^{-1}$; Gilliam and Smith, 1980) and negatively correlated with shoot growth (Table 3).

Fig. 1. Dry weight of shoots, leaves, stems and roots, and shoot/root dry weight ratio of ninebark in response to various compost leachates (uMSW = unamended municipal solid waste; aMSW = amended municipal solid waste; uTLC = unamended turkey litter compost; aTLC = amended turkey litter compost). Leachate treatments with different letters are significantly different by LSD $(P \leq 0.05)$. The horizontal dotted lines represent growth with the two control treatments. $\mathrm{NRC}=$ nonrecirculated control, $\mathrm{RC}=$ recirculated control. Comparisons to the controls were made using Dunnett's test at $P \leq 0.05$. 'Significant difference from NRC. *Significant difference from RC.
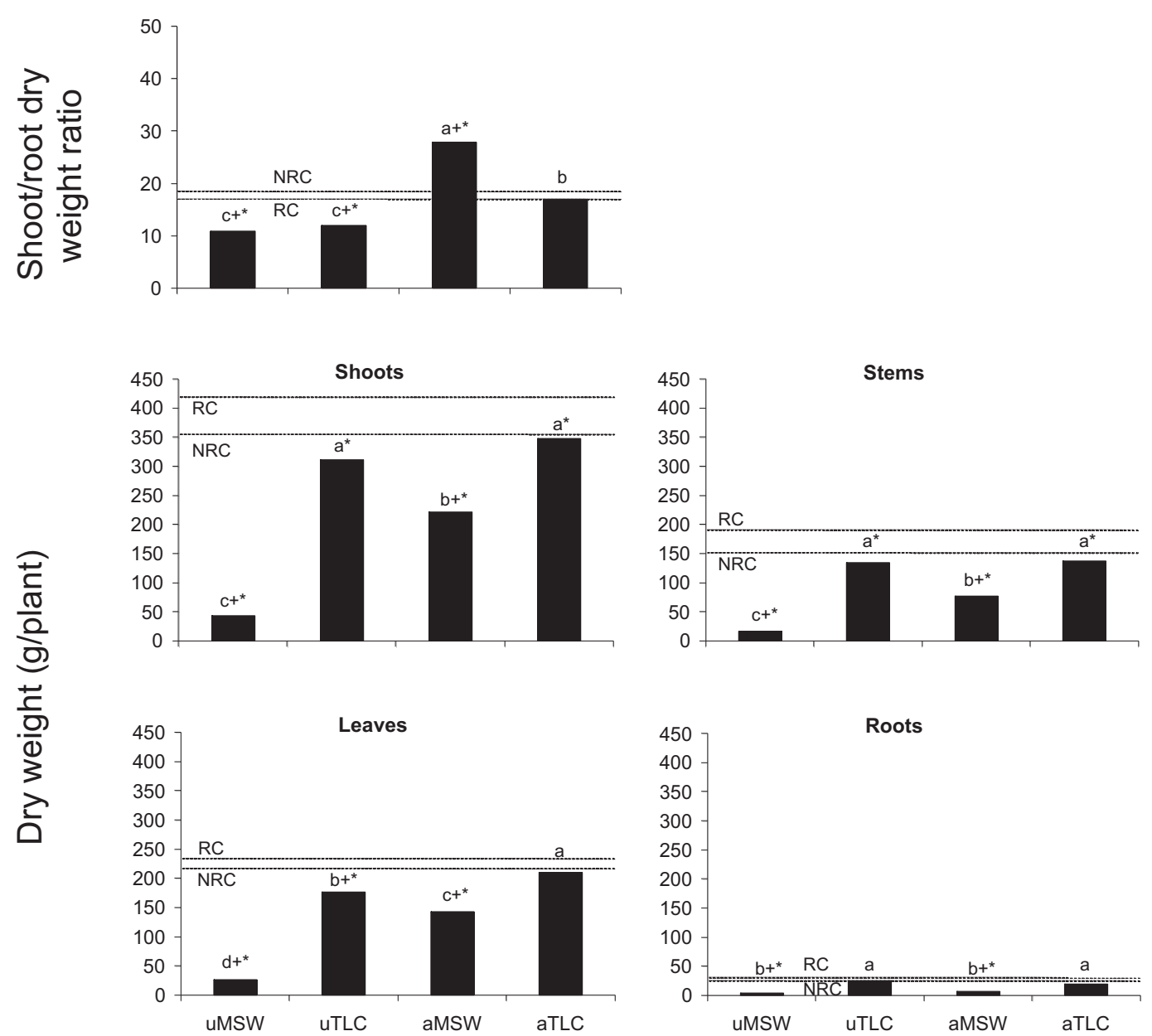
The additional $\mathrm{NO}_{3}-\mathrm{N}\left(129 \mathrm{mg} \cdot \mathrm{L}^{-1}\right)$ in the solution formula (Table 1) may have reduced $\mathrm{Cl}$ toxicity symptoms (relative to unamended MSW plants) as $\mathrm{NO}_{3}-\mathrm{N}$ tends to compete with $\mathrm{Cl}$ for uptake (Mills and Jones, 1996).

The impaired root growth with the MSW leachates is interesting since this did not occur with the TLC leachates. Although the plant tissue was not analyzed for heavy metal contents, typical symptoms of heavy metal
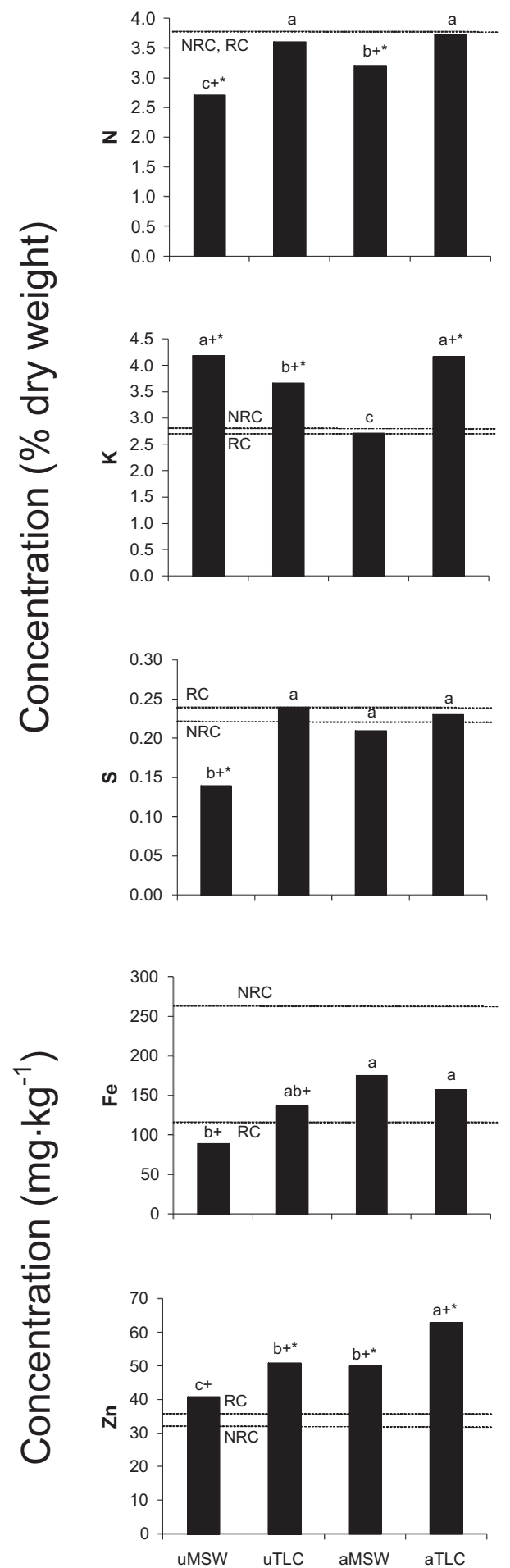
major constraints for plant growth in medium

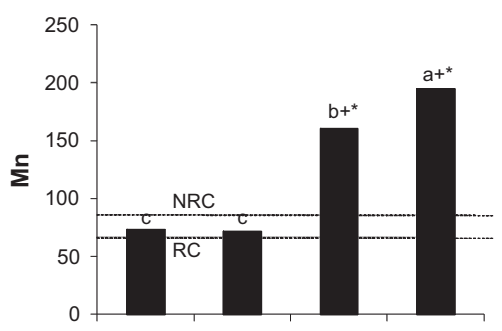

toxicity (root damage and chlorosis similar to that induced by Fe deficiency; Bergmann, 1992) were not seen. As Cland $\mathrm{Na}$ are the two to high salinity conditions, the notably higher concentrations of these nutrients in the MSW leachate versus the TLC leachate, may have interfered with root development (Baligar et al., 1998; Schwarz, 1985). It is also possible that phytotoxic organic compounds, such as
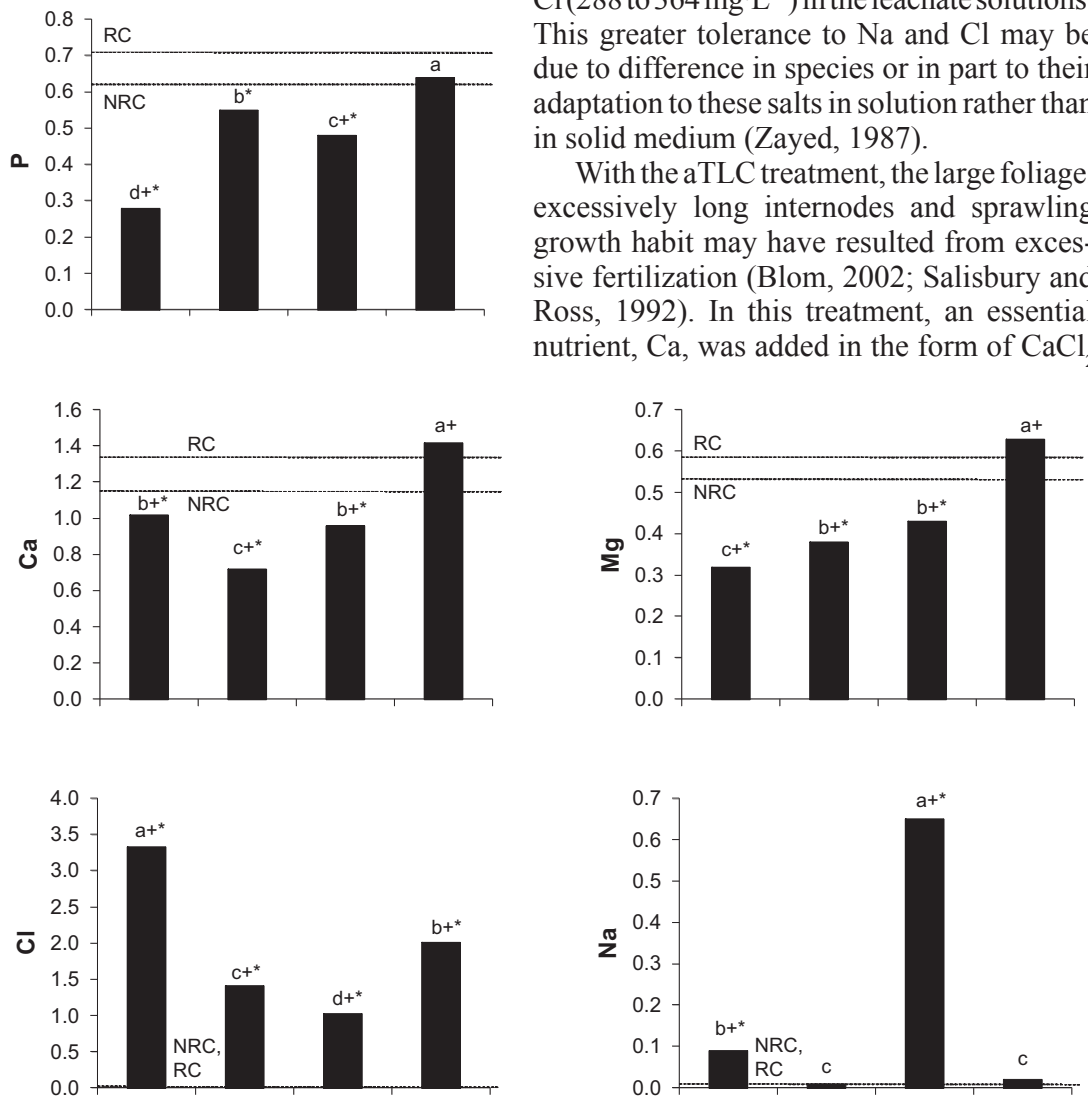

phenols, may have been present in the MSW leachates (Öman and Hynning, 1993; Revel et al., 1999; Shrive et al., 1994).

Using the same MSW leachate source in stationary hydroponic solutions, Michitsch et al. (2003) found that both unamended and amended leachates produced tops and roots of forsythia and weigela equal to or larger than those with a control solution, despite high concentrations of $\mathrm{Na}\left(137\right.$ to $\left.173 \mathrm{mg} \cdot \mathrm{L}^{-1}\right)$ and $\mathrm{Cl}\left(288\right.$ to $\left.364 \mathrm{mg} \cdot \mathrm{L}^{-1}\right)$ in the leachate solutions. This greater tolerance to $\mathrm{Na}$ and $\mathrm{Cl}$ may be due to difference in species or in part to their adaptation to these salts in solution rather than in solid medium (Zayed, 1987).

With the aTLC treatment, the large foliage, excessively long internodes and sprawling growth habit may have resulted from excessive fertilization (Blom, 2002; Salisbury and Ross, 1992). In this treatment, an essential nutrient, $\mathrm{Ca}$, was added in the form of $\mathrm{CaCl}_{2}$

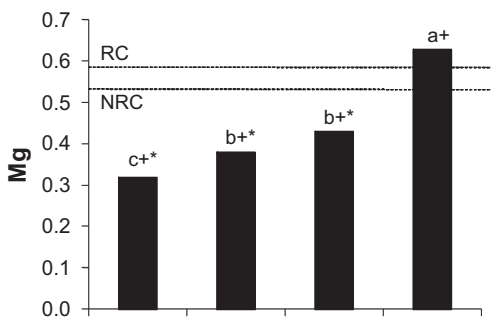

0
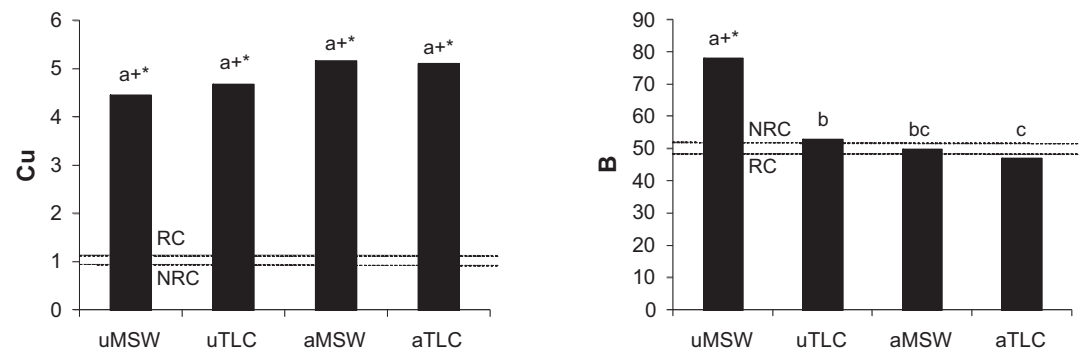

Fig. 2. Foliar nutrient concentrations of ninebark in response to various compost leachates. uMSW = unamended municipal solid waste; aMSW = amended municipal solid waste; uTLC $=$ unamended turkey litter compost; aTLC $=$ amended turkey litter compost). Leachate treatments with different letters are significantly different by LSD $(P \leq 0.05)$. The horizontal dotted lines represent concentrations with the two control treatments. NRC $=$ nonrecirculated control, $\mathrm{RC}=$ recirculated control. Comparisons to the controls were made using Dunnett's test at $P \leq 0.05$. ${ }^{+}$Significant difference from NRC. "Significant difference from RC. 
Table 3. Correlations (r) between shoot, stem, leaf and root dry weights and foliar nutrient concentrations in ninebark.

\begin{tabular}{|c|c|c|c|c|c|c|c|c|c|c|c|c|c|}
\hline \multirow[b]{2}{*}{ Dry wt } & \multicolumn{13}{|c|}{ Foliar nutrient } \\
\hline & $\mathrm{N}$ & $\mathrm{P}$ & $\mathrm{K}$ & $\mathrm{Ca}$ & $\mathrm{Mg}$ & $\mathrm{S}$ & $\mathrm{Cl}$ & $\mathrm{Na}$ & $\mathrm{Fe}$ & $\mathrm{Mn}$ & $\mathrm{Zn}$ & $\mathrm{Cu}$ & B \\
\hline Shoot & $0.90^{* *}$ & $0.91^{* *}$ & $-0.42^{*}$ & 0.35 & $0.72^{* *}$ & $0.83^{* *}$ & $-0.78^{* *}$ & -0.30 & 0.36 & 0.06 & 0.05 & $-0.48^{*}$ & $-0.84^{* *}$ \\
\hline Stem & $0.88^{* *}$ & $0.89^{* *}$ & -0.40 & 0.31 & $0.66^{* *}$ & $0.79^{* *}$ & $-0.75^{* *}$ & -0.39 & 0.26 & -0.07 & -0.001 & $-0.53^{*}$ & $-0.77^{* *}$ \\
\hline Leaf & $0.90^{* *}$ & $0.91^{* *}$ & $-0.44^{*}$ & 0.37 & $0.75^{* *}$ & $0.83^{* *}$ & $-0.78^{* *}$ & -0.23 & $0.42^{*}$ & 0.15 & 0.10 & $-0.43^{*}$ & $-0.87^{* *}$ \\
\hline Root & $0.83^{* *}$ & $0.80^{* *}$ & -0.20 & 0.16 & $0.51^{*}$ & $0.71^{* *}$ & $-0.58^{* *}$ & $-0.56^{* *}$ & 0.16 & -0.20 & 0.05 & $-0.45^{*}$ & $-0.65^{\text {** }}$ \\
\hline
\end{tabular}

${ }^{*, * *}$ Significant at $P \leq 0.05$ or 0.01 , respectively; $\mathrm{n}=22$.
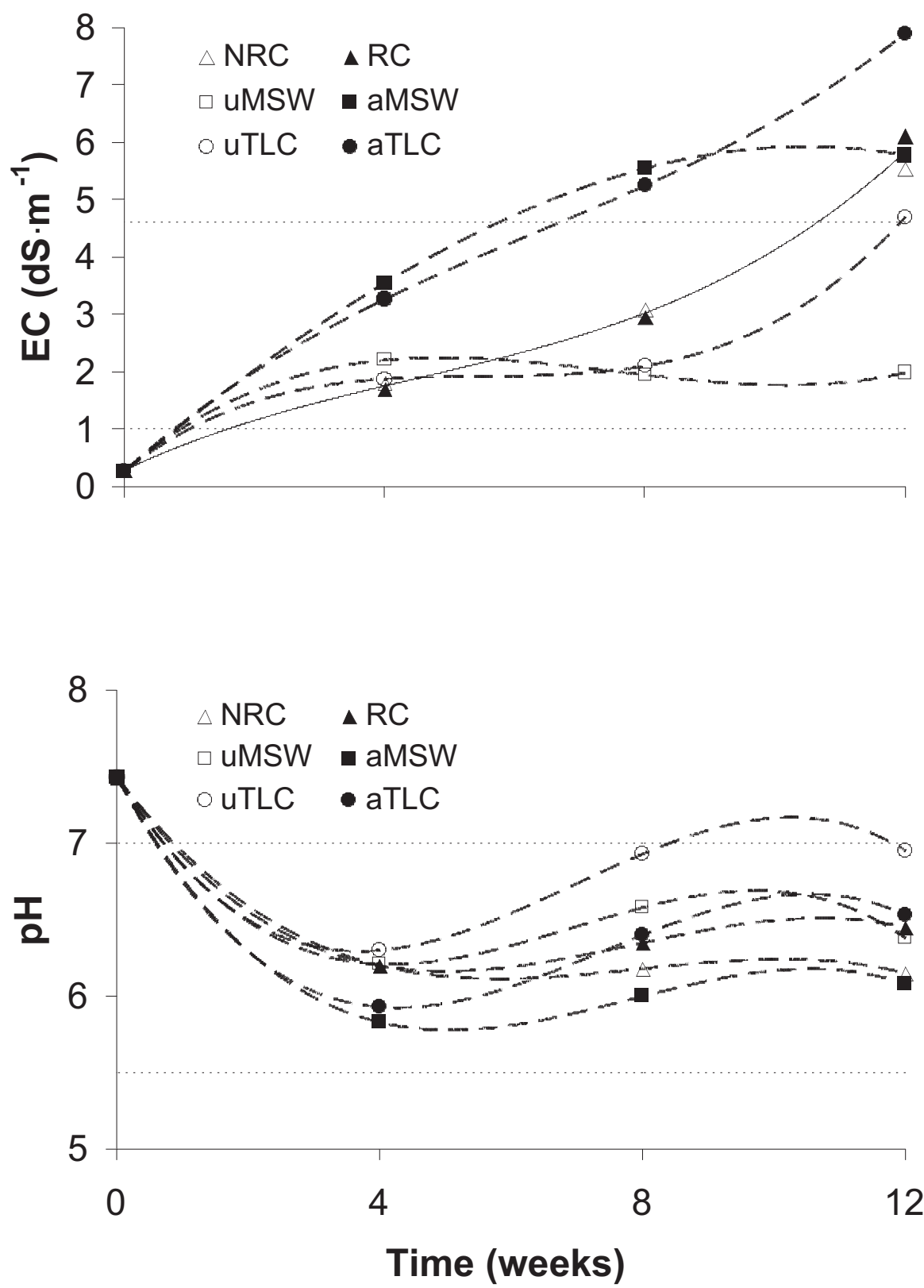

Fig. 3. Substrate $\mathrm{EC}$ and $\mathrm{pH}$ of ninebark in response to two control and four compost leachate treatments over time. When two regressions were not significantly different at $P \leq 0.05$, a common regression (solid line) was fitted. The horizontal broken lines represent the desirable upper and lower EC $\left(1.0-4.6 \mathrm{dS} \cdot \mathrm{m}^{-1}\right.$; BCMAF, 1999) and $\mathrm{pH}(5.5-7.0$; OMAF, 2003) thresholds for container-grown nursery crops. NRC = nonrecirculated control; $\mathrm{RC}=$ recirculated control; uMSW = unamended municipal solid waste; aMSW = amended municipal solid waste; uTLC $=$ unamended turkey litter compost; aTLC $=$ amended turkey litter compost. Regression equations for substrate $\mathrm{EC}$ (partial $\left.r^{2}=0.98\right)$ : NRC and RC, $\mathrm{y}=0.28+0.55 \mathrm{x}-0.063 \mathrm{x}^{2}$ $+0.0048 \mathrm{x}^{3} ; \mathrm{uMSW}, \mathrm{y}=0.28+0.97 \mathrm{x}-0.15 \mathrm{x}^{2}+0.0065 \mathrm{x}^{3} ; \mathrm{aMSW}, \mathrm{y}=0.28+0.93 \mathrm{x}-0.023 \mathrm{x}^{2}-0.0014 \mathrm{x}^{3}$; uTLC, $\mathrm{y}=0.28+0.89 \mathrm{x}-0.16 \mathrm{x}^{2}+0.0098 \mathrm{x}^{3}$; aTLC, $\mathrm{y}=0.28+1.0 \mathrm{x}-0.085 \mathrm{x}^{2}+0.0044 \mathrm{x}^{3}$. Regression equations for substrate $\mathrm{pH}$ (partial $r^{2}=0.93$ ): NRC, $\mathrm{y}=7.4-0.56 \mathrm{x}+0.076 \mathrm{x}^{2}-0.0031 \mathrm{x}^{3} ; \mathrm{RC}, \mathrm{y}=7.4$ $-0.60 \mathrm{x}+0.088 \mathrm{x}^{2}-0.0037 \mathrm{x}^{3} ; \mathrm{uMSW}, \mathrm{y}=7.4-0.69 \mathrm{x}+0.12 \mathrm{x}^{2}-0.0056 \mathrm{x}^{3} ; \mathrm{aMSW}, \mathrm{y}=7.4-0.78 \mathrm{x}+0.11 \mathrm{x}^{2}$ $-0.0049 \mathrm{x}^{3} ;$ uTLC, $\mathrm{y}=7.4-0.70 \mathrm{x}+0.13 \mathrm{x}^{2}-0.0061 \mathrm{x}^{3}$; aTLC, $\mathrm{y}=7.4-0.82 \mathrm{x}+0.13 \mathrm{x}^{2}-0.0061 \mathrm{x}^{3}$.

to the TLC leachate, which also increased the $\mathrm{Cl}$ concentration to $200 \mathrm{mg} \cdot \mathrm{L}^{-1}$ (Table 1 ). Mild ( $<5 \%$ of leaves affected) symptoms of appar- ent $\mathrm{Cl}$ toxicity were evident on aTLC plants on 21 June; however, symptoms increased in severity after this date as the concentration in solution increased to $239 \mathrm{mg} \cdot \mathrm{L}^{-1}$. Tissue $\mathrm{Ca}$ in UTLC plants was sufficient despite low concentrations in the leachate (near $30 \mathrm{mg} \cdot \mathrm{L}^{-1}$ Table 1). Therefore, the use of $\mathrm{CaCl}_{2}$ could have been avoided.

Dark brown spots on the older leaves of aTLC plants, similar to those observed on uMSW plants, suggested possible B toxicity; however, the concentration of $\mathrm{B}\left(47 \mathrm{mg} \cdot \mathrm{kg}^{-1}\right)$ in the leaf tissue was normal (Gilliam and Smith, 1980). The spotting, in combination with the loss of apical dominance, could have resulted from Mn toxicity, as the leaf tissue concentration $\left(195 \mathrm{mg} \cdot \mathrm{kg}^{-1}\right)$ was highest in this treatment (Marschner, 1986). Further experimentation is required to differentiate the symptoms observed herein, as diagnosing the symptoms of nutritional disorders can be especially difficult when more than one mineral nutrient is deficient or toxic, or when there is a deficiency of one nutrient and, simultaneously, toxicity of another (Marschner, 1986).

Berry et al. (1977), working with container grown plants, found that iron deficiency could be a problem in unamended water. Foliar Fe contentrations with the unamended leachates were lower than with the nonrecirculated control(Fig. 2), but were similar to the recirculated control. Thus, foliar Fe concentrations were not considered to be deficient (Gilliam and Smith, 1980). The concentrations of other micronutrients were higher with the unamended $(\mathrm{Zn}$ and $\mathrm{Cu})$ and amended $(\mathrm{Zn}, \mathrm{Cu}$, and $\mathrm{Mn}$ ) compost leachate solutions compared to the control solutions. As reported by Gratten and Grieve (1999), the uptake of Mn, Zn, and $\mathrm{Cu}$ can increase in crop plants under salinity stress. Concentrations of $\mathrm{Cu}$ were lower than recommended (Gilliam and Smith, 1980) for all treatments. However, control plants showed no symptoms of $\mathrm{Cu}$ deficiency, therefore concentrations were considered adequate or tolerable.

Raymond et al. (1998) found that initial substrate EC values were positively correlated with growth of each of four container-grown shrubs. Chong (1999) found that end-of-season growth of three woody species was positively correlated with early season ['Minnesota Snowflake' mockorange (Philadelphus $\times$ virginalis Rehd. 'Minnesota Snowflake')] and midseason [silverleaf dogwood (Cornus alba L. 'Argenteo-marginata') and variegated weigela (Weigela florida (Bunge.) A. DC. 'Variegata Nana')] substrate EC readings. In this study, we found substrate EC positively correlated with shoot dry weight on the final sampling date $\left(r=0.79^{*}\right)$. The (a) upward trend in substrate EC throughout the 12 week study for all leachate solutions, except uMSW, and (b) above-recommended EC values observed in the two amended solutions during the later 
half of the study, and also in the two control solutions close to harvest (Fig. 3), suggest that to maintain container nursery plants for a longer period of time would likely require periodic emptying of the solution tanks (Zekki et al., 1996) and/or flushing of the substrate with water to reduce the possibility of toxic salt buildup (Resh, 1989).

\section{Conclusion}

In a comparative study using recirculated turkey litter and municipal solid waste compost leachate solutions as nutrient sources, each unamended or fortified with extra nutrients, container-grown ninebark grew acceptably well only with the unamended turkey litter leachate. In this solution, the concentration of nutrients, especially $\mathrm{NO}_{3}-\mathrm{N}, \mathrm{P}$, and $\mathrm{K}$ were close to or within normal ranges. Comparative quantitative data for growth, foliar nutrient contents and nutrient changes measured in the treatment solutions and container substrate during the experiment, indicate that poorer results with the other leachates were due to imbalances or disorders of one or more nutrients. Notwithstanding the preliminary nature of this study, the results show promise for using and recirculating compost leachates in commercial production.

\section{Literature Cited}

Ayers, R.S. and D.W. Westcot. 1985. Water quality for agriculture. FAO irrigation and drainage paper 29, Rev. 1. FAO, Rome.

Baligar, V.C., N.K. Fageria, and M.A. Elrashidi. 1998. Toxicity and nutrient constraints on root growth. HortScience 33:960-965.

Bergmann, W. 1992. Nutritional disorders of plants. VCH Publishers, Deerfield Beach, Fla.

Berry, W.L., A. Wallace, and O.R. Lunt. 1977. Recycling municipal wastewater for hydroponic culture. HortScience 12:186.

Blom, T.J. 2002. Plant nutrition. Dept. Plant Agr., Univ. Guelph, Vineland Station, Ont.

Böhme, M. 1995. Effects of closed systems in substrate culture for vegetable production in greenhouses. Acta Hort. 396:45-54.

British Columbia Ministry of Agriculture and Food (BCMAF). 1996. Composting-Environmental concerns. 26 June 2003. http://www. agf.gov.bc.ca/resmgmt/publist/300series/ 382500\%2D11.pdf.

British Columbia Ministry of Agriculture and Food (BCMAF). 1999. On-site testing of growing media and irrigation water. 26 June 2003. http:// florawww.eeb.uconn.edu/pdf/BCMAF\%20Ons ite $\% 20$ Testing $\% 20$ of $\% 20$ Media $\% 20$ and $\% 20$ Irr igation $\% 20$ Water.pdf.

Bunt, A.C. 1988. Media and mixes for containergrown plants. 2nd ed. Unwin Hyman, London.

Canadian Nursery Landscape Association (CNLA). 2002. Canadian standards for nursery stock. 7th ed. Canadian Nursery Landscape Association,
Milton, Ont.

Chong, C. 1999. Blending slow-release fertilizers for container nursery culture. Comb. Proc. Intl. Plant Prop. Soc. 49:287-292.

Chong, C. 2002. Use of waste and compost in propagation: Challenges and constraints. Comb. Proc. Intl. Plant Prop. Soc. 52:410-414.

Chong, C. and P. Purvis. 2004. Nursery crop response to substrates amended with raw paper mill sludge, composted paper mill sludge and composted municipal waste. Can. J. Plant Sci. 84:1127-1134.

Deveau, J., D.P. Ormrod, O.B. Allen, and D. Beckerson. 1987. Growth and foliar injury responses to maize, soybean and tomato seedlings exposed to mixtures of ozone and sulphur dioxide. Agr. Ecosyst. Environ. 19:223-240.

Fitzpatrick, G.E. 1984. Repercussions of rationing. Interior Landscape Ind. 1(7):37-39.

Gilliam, C.H. and E.M. Smith. 1980. Fertilization of container-grown nursery stock. Ohio State Univ. Coop. Ext. Serv. Bul. 658.

Gratten, S.R. and C.M. Grieve. 1999. Mineral nutrient acquisition and response by plants grown in saline environments, p. 203-230. In: M. Pessarakli (ed.). Handbook of plant and crop stress. Marcel Dekker, New York.

Jarecki, M. 2002. Evaluation of compost leachates as a source of irrigation water and nutrients in field and hydroponic experiments. PhD thesis. Univ. Guelph, Guelph, Ont.

Jarecki, M.K., C. Chong, and R.P. Voroney. 2005. Evaluation of compost leachates for plant growth in hydroponic culture. J. Plant Nutr. 28:1-17.

Li, Y.C., P.J. Stofella, A.K. Alva, D.V. Calvert, and D.A. Graetz. 1997. Leaching of nitrate, ammonium, and phosphate from compost amended soil columns. Compost Sci. Util. 5:63-67.

Marschner, H. 1986. Mineral nutrition of higher plants. Academic Press, San Diego.

Mathers, H. 2000. Root rots and recirculated water. The Digger 44:48.

Mathers, H. 2003. What you should know about water quality for woody plants: Part $1.8 \mathrm{Nov}$. 2003. http://www.greenbeam.com/cyberconference/woody-plants $1 . h$ tml.

Michitsch, R., C. Chong, R.P. Voroney, B. Holbein, and H.W. Liu. 2003. Use of spent mushroom compost leachate for growing turf and nursery species in hydroponic culture. Mushroom World 14(3):21-23.

Mills, H.A. and J.B. Jones, Jr. 1996. Plant analysis handbook II. Micro Macro Publ., Jefferson City, Mo.

Öman, C. and P. Hynning. 1993. Identification of organic compounds in municipal landfill leachates. Environ. Pollut. 80:265-271.

Ontario Ministry of Agriculture and Food (OMAF). 2003. Nursery and landscape plant production and IPM. Publ. 383. Queen's Printer for Ontario, Toronto.

Peot, C. and O. McIntyre. 2000. Generating revenue from compost facility runoff. BioCycle 41:34-36.

Poole, R.T. and C.A. Conover. 1992. Fertilizer levels and medium affect foliage plant growth in an ebb and flow irrigation system. J. Environ. Hort. 10:81-86.
Purvis, P., C. Chong, and G.P. Lumis. 2000. Recirculation of nutrients in container nursery production. Can. J. Plant Sci. 80:39-45.

Raymond, D.A., C. Chong, and R.P. Voroney. 1998. Response of four container grown woody ornamentals to immature composted media derived from waxed corrugated cardboard. Compost Sci. Util. 6:67-74.

Reisenauer, H.M. 1976. Soil and plant-tissue testing in California. Bul. 1879, Div. Agr. Sci., Univ. Calif.

Resh, H.M. 1989. Hydroponic food production. 4th ed. Woodbridge Press Publ. Co., Santa Barbara, Calif.

Revel, J.C., P. Morard, J.R. Bailly, H. Labbé, C. Berthout, and M. Kaemmerer. 1999. Plants' use of leachate derived from municipal solid waste. J. Environ. Qual. 28:1083-1089.

Rose, M.A. and B. Biernacka. 1999. Seasonal patterns of nutrient and dry weight accumulation in Freeman maple. HortScience 34:91-95.

Salisbury, F.B. and C.W. Ross. 1992. Plant physiology. 4th ed. Wadsworth, Belmont, Calif.

Schulz, R. and U. Romheld. 1997. Recycling of municipal and industrial organic wastes in agriculture: Benefits, limitations and means of improvement, p. 581-586. In: Plant nutrition for sustainable food production and environment. Kluwer Academic Publishers, Boston.

Schwarz, M. 1985. The use of saline water in hydroponics. Soilless Cult. 1:25-34.

Shrive, S.C., R.A. McBride, and A.M. Gordon. 1994. Photosynthetic and growth responses of two broad-leaf tree species to irrigation with municipal landfill leachate. J. Environ. Qual. 23:534-542.

Sonneveld, C. and A.M.M. Vanderburg. 1991. Sodium chloride salinity in fruit vegetable crops in soilless culture. Netherlands J. Agr. Sci. 39:115-122.

Southern Nurserymen's Association. 1997. Best management guide for producing containergrown plants. S. Nurserymen's Assn., Marietta, Ga.

Transportation Association of Canada. 2003. Syntheses of best practices road salt management. 6.0: Vegetation management. 5 Jan. 2004. http:// www.tac-atc.ca/English/pdf/vegetation.PDF.

Weltzien, H.C. 1992. Biocontrol of foliar fungal diseases with compost extracts, p. 430-450 In: J.H. Andrews and S.S. Hirano (eds.). Microbial ecology of leaves. Springer-Verlag, New York.

Whipker, B. 1999. Irrigation water quality for container-grown plants. 8 Nov. 2003. http://www. extension.iastate.edu/Publications/PM1699. pdf.

Wright, R.D. 1986. The pour-through nutrient extraction procedure. HortScience 21:227-229.

Zayed,A.M. 1987. The influence of sodium chloride on the ion uptake and yield of tomatoes and lettuce grown in hydroponics. $\mathrm{PhD}$ thesis. Univ. London, London.

Zekki, H., L. Gauthier, and A. Gosselin. 1996. Growth, productivity, and mineral composition of hydroponically cultivated greenhouse tomatoes, with or without nutrient solution recycling. J. Amer. Soc. Hort. Sci. 121:1082-1088. 